\title{
HUBUNGAN SIKAP SISWA TERHADAP PERHATIAN ORANG TUA KARIR DENGAN PRESTASI KOGNITIF MEREKA PADA MATA PELAJARAN PAI DI SEKOLAH (Penelitian terhadap Siswa Kelas VII di SMP Karya Budi Bandung)
}

\author{
Laela Nurjalilah ${ }^{1)}$ \\ ${ }^{1)}$ Universitas Islam Negeri Sunan Gunung Djati Bandung, Jln. A.H. Nasution No. 105 \\ Cipadung, Bandung, 40
}

Email: nurjalilah.laela04@gmail.com

\begin{abstract}
The purpose of this study was to find out (1) the reality of students' assessment of career parents given to children, (2) the relationship of student tolerance to careers' parents' care given to children with their cognitive appreciation on PAI subjects. This study departs from a hypothesis that states positively towards students towards parents, the better their cognitive achievement on PAI subjects. Quantitative research, descriptive method, which is used to analyze empirical phenomena that occur in the present by describing the results of existing research. The sample was 32 students from Budi Bandung Middle School. The technique collects the data by observing interviews, questionnaires, tests. The analysis process is carried out partially and correlatively. The results showed that students 'attitudes towards careers' parents 'attention were given to children not correlated with their cognitive achievement on PAI subjects with the degree of influence of variable $X$ on variable $Y$ was $5 \%$ while $95 \%$ was used by other factors, based on students' motivation towards people's attention old career.
\end{abstract}

Keywords:

Attention, Parents, Student Attitudes, Cognitive Achievement.

\begin{abstract}
Abstrak : Tujuan penelitian ini adalah untuk mengetahui (1) realitas sikap siswa terhadap perhatian orang tua karir yang diberikan kepada anak-anaknya, (2) realitas prestasi kognitif siswa pada mata pelajaran PAI, dan (3) realitas hubungan sikap siswa terhadap perhatian orang tua karir yang diberikan kepada anakanaknya dengan prestasi kognitif mereka pada mata pelajaran PAI. Penelitian ini bertolak dari hipotesis yang menyatakan bahwa semakin positif sikap siswa terhadap perhatian orang tua karir, semakin baik pula prestasi kognitif mereka pada mata pelajaran PAI. Penelitian kuantitatif, metodenya deskriptif, yang digunakan untuk menganalisis fenomena empirik yang terjadi pada masa sekarang dengan cara melukiskan hasil penelitian apa adanya. Sampelnya 32 orang siswa SMP Karya Budi Bandung. Teknik pengumpulan datanya dengan Observasi wawancara, angket, tes. Proses analisisnya dilakukan secara parsial dan korelasional. Hasil penelitian menunjukkan bahwa sikap siswa terhadap perhatian orang tua karir diberikan kepada anak tidak berkorelasi dengan prestasi kognitif mereka pada mata pelajaran PAI dengan derajat pengaruh variabel $\mathrm{X}$ terhadap variabel Y sebesar 5\% sedangkan 95\% lagi dipengaruhi oleh faktor lain, selain faktor sikap siswa terhadap perhatian orang tua karir.
\end{abstract}

Kata Kunci:

Perhatian, Orang Tua, Sikap Siswa, Prestasi Kognitif.

\section{PENDAHULUAN}

Wanita mempunyai peranan penting dalam melahirkan umat terbaik. Wanita harus menjadi istri yang baik, ibu yang baik, dan sekaligus sekolah yang baik. Jika suatu umat ingin bangkit dan menempati kedudukan yang mulia, maka hal pertama yang mesti dilakukan adalah memperbaiki pendidikan pertama (yaitu ibu) sehingga, dengan begitu, seorang ibu betul-betul menjadi sekolah. Ini sebagaimana yang juga telah dikatakan 
Hafizh Ibrahim, seorang penyair modern; "ibu laksana sekolah jika engkau mempersiapkannya suatu bangsa yang besar".

Persoalannya kemudian, bagaimana pendidikan keluarga berlangsung pada orang tua karir dimana seorang kedua orang tua lebih banyak menghabiskan waktunya diluar rumah. Bila kita lihat apa yang dikatakan oleh Hafizh Ibrahim di atas, tampaknya hal itu lebih menunjuk pada keluarga konvensional dimana ibu menghabiskan seluruh waktunya untuk mengurus anak dirumah. Persoalan anak seperti broken home dan tauran agaknya lahir dari persoalan yang salah satunya ditimbulkan oleh orang tua karir, mengingat kedua orangtuanya sibuk pada kegiatan diluar rumberah sehingga anak merasa kurang perhatian dan mencari pada konpensasi pada hal-hal yang negatif (zamah 2007, 11-12). Pengaplikasian pembinaan akhlak siswa di lingkungan pendidikan dengan cara senantiasa meningkatkan pembinaan anak di rumah dan di Madrasah dengan pemberian pengetahuan agama, pembiasaan akhlak karimah dan kedisiplinan dalam meningkatkan akhlak mulia siswa.

Keterpaduan antara pendidik di sekolah, rumah dan masyarakat diharapkan dapat meningkatkan mutu pendidikan yang menurut Hasbiyallah (2012) lulusannya mampu hidup mandiri, produktif, dan kreatif (qiyamuhu binafsihi) dan mampu memberikan kebaikan kepada semua makhluk (rahmatan lil 'alamin).

Berdasarkan hal tersebut diatas, maka perhatian orang tua merupakan sesuatu emberianyang amat penting dalam usaha pencapaian prestasi anak, dengan diketahui prestasi belajar dikelas bagi siswa merupakan pengalaman yang menyenangkan yang memperkuat dorongan untuk belajar kembali.

Sikap merupakan kesiapan atau kesediaan untuk bertindak dan bukan pelaksanaan motif tertentu. Dapat diartikan juga bahwa sikap adalah kecenderungan bertindak, berpikir, berpersepsi, dan meraa dalam mengahadapi objek, ide, situasi, atau nilai sikap bukanlah perilaku, tetapi merupakan kecenderungan untuk berperilaku dengan cara tertentu terhadap objek sikap. Sikap relatif lebih menetap atau jarang mengalami perubahan.

Hasil studi pendahuluan, di SMP Karya Budi Bandung, khususnya di kelas VII, orang tua dari masing-masing siswa telah memberikan perhatian dan bimbingan belajar yang lebih kepada anaknya walaupun mereka sibuk dengan pekerjaannya masingmasing, hal ini terbukti dengan pemberian keperluan material anak, menciptakan suasana Home bagi anak seperti pemberian bimbingan dan nasehat, dan tugas pendidikan pada anak seperti pemberian pengawasan terhadap belajar, pemberian motivasi dan penghargaan serta pemenuhan fasilitas belajar. Namun pada kenyataan nya walaupun orang tua siswa telah memberikan perhatian dan bimbingan belajar yang lebih kepada anak-anaknya tapi seolah mereka tidak menyadari apa yang telah diberikan oleh kedua orangtua nya, bahkan sampai masih ada terdapat siswa yang acuh tak acuh dalam merespon hal tersebut sehingga dalam belajar mereka malas dan kurangnya respon mereka terhadap materi yang di ajarkan dalam proses pembelajaran khususnya pada pelajaran agama sehingga menimbulkan nilai rata-rata di bawah KKM yaitu 7,5. 
Dari fenomena empirik diatas, menunjukan adanya kesenjangan, yaitu di satu sisi orang tua memberikan hak nya sebagaimana kodrat dari orangtua yaitu memberikan perhatian dan bimbingan yang lebih dalam belajar khususnya yang bertujuan agar anak itu melakukan belajar dengan giat dirumah maupun di sekolah dan mendorong anak untuk berprestasi, di sisi lain ternyata masih ada sebagian anak yang bersikap acuh karena tidak termotivasi dengan adanya prestasi.

Berdasarkan latar belakang masalah di atas, maka beberapa masalah dapat dirumuskan sebagai berikut:

1. Bagaimana sikap siswa kelas VII terhadap perhatian orang tua karir di SMP Karya Budi Bandung?

2. Bagaimana prestasi kognitif siswa pada mata pelajaran PAI kelas VII di SMP Karya Budi Bandung?

3. Bagaimana Hubungan sikap siswa terhadap perhatian orang tua karir dengan prestasi kognitif mereka pada mata pelajaran PAI kelas VII di SMP Karya Budi Bandung?

Sesuai dengan rumusan masalah penelitian yang ada, maka tujuan penelitian ini adalah untuk mengetahui:

1. Sikap siswa kelas VII terhadap Perhatian orang tua karir di SMP Karya Budi Bandung

2. prestasi kognitif siswa pada pelajaran PAI kelas VII di SMP Karya Budi Bandung

3. Hubungan sikap siwa terhadap perhatian orang tua karir dengan prestasi kognitif mereka pada mata pelajaran PAI kelas VII di SMP Karya Budi Bandung.

Trow mendefinisikan sikap sebagai suatu kesiapan mental atau emosional dalam beberapa jenis tindakan pada situasi yang tepat . di sini Trow lebih menekankan pada kesiapan mental atau emosional seseorang terhadap sesuatu objek. Sementara itu Allport seperti dikutip oleh Gable mengemukakan bahwa sikap adalah sesuatu kesiapan mental dan saraf yang tersusun melalui pengalaman dan memberikan pengaruh langsung kepada respons individu terhadap semua objek atau situasi yang berhubungan dengan objek itu.

Menurut Ahmadi (2007:159) bahwa mengajarkan sikap adalah merupakan tanggung jawab orang tua atau lembaga-lembaga keagamaan. Di sekolah sebenarnya memiliki tugas pula dalam membina sikap. Bukankah tujuan pendidikan baik di sekolah maupun di luar sekolah adalah mempengaruhi, membawa, membimbing anak agar memiliki sikap seperti yang diharapkan pada tujuan pendidikan.

Berdasarkan pendapat di atas dalam mengajarkan sikap adalah tanggung jawab orangtua bila di rumah. Di rumah sikap orangtua biasanya ditiru oleh anak-anak. Orangtua adalah model bagi anak-anak, karena anak-anak hanya bisa mencontoh apa yang dilakukan orangtuanya. Untuk itu sikap yang perhatian dari orangtua sangat diperlukan dalam pendidikan anak-anak. Pada saat di sekolah sikap anak-anak itu bisa 
melalui tanggung jawab guru saat di sekolah dalam membina sikap anak-anak untuk lebih baik lagi.

Pendidikan agama yang diberikan sejak dini menuntut peran serta keluarga, karena telah diketahui sebelumnya bahwa keluarga merupakan institusi pendidikan yang pertama dan utama yang dapat memberikan pengaruh kepada anak. Pelaksanaan pendidikan agama pada anak dalam keluarga dipengaruhi oleh adanya dorongan dari anak itu sendiri dan juga adanya dorongan keluarga.

Setiap orang mengharapkan rumah tangga yang aman, tentram dan sejahtera. Dalam kehidupan keluarga, setiap keluarga mendambakan anak- anaknya menjadi anakanak yang sholeh dan sholehah. Anak merupakan amanat Allah SWT kepada orang tuanya untuk diasuh, dipelihara, dan dididik dengan sebaik-baiknya.

Perhatian orang tua kacir adalah perhatian yang diberikan orang tua kepada anaknya dalam bentuk bimbingan belajar, sedangkan kedua orang tuanya sibuk bekerja di luar rumah. Berdasarkan jenis pekerjaan, swasta, atau negeri, orang tua karir terbagi tiga, pertama orang tua karir di mana suami dan istri bekerja sebagai pegawai negeri. Kedua, suami atau istri bekerja pada perkerjaan swasta. Ketiga, orang tua di mana suami bekerja sebagai pegawai negeri sementara istrinya sebagai pegawai swasta atau sebaliknya. Dalam hal ini baik suarni atau istri mungkin saja sebagai hakim, dosen, perwira militer, birokrat atau pemimpin perusahan. Pembagian ini tentu saja bisa dengan berdasarkan tinggi rendahnya jabatan yang diduduki orang tua karir.(Aa Zam'ah, 2007:21)

Perhatian orang tua memiliki pengaruh psikologis yang besar terhadap kegiatan belajar anak. Dengan adanya perhatian dari orang tua, anak akan lebih giat dan lebih bersemangat dalam belajar karena ia tahu bahwa bukan dirinya sendiri saja yang berkeinginan untuk maju, akan tetapi orang tuanya pun demikian. Sebab baik buruknya prestasi yang dicapai anak akan memberikan pengaruh kepadanya dalam perkembangan pendidikan selanjutnya.

Begitupun yang terjadi pada orang tua karir yang setiap hari bekerja di luar rumah, meskipun keadaan keduanya sangat sibuk, akan tetapi tidak baik mengabaikan tanggung jawab utamanya, yakni memperhatikan pendidikan anak. Karena dengan perhatian kedua orang tua itulah prestasi belajar anak akan meningkat.

Menurut Muhibbin Syah (2012:22) Istilah cognitive berasal dari kata cognition yang padanannya knowing, berarti mengetahui. Dalam arti yang luas, cognition (kognisi) ialah perolehan, penataan, dan penggunaan pengetahuan (Neisser, 1976). Dalam perkembangan selanjutnya, istilah kognitif menjadi populer sebagai salah satu domain atau wilayah/ranah psikologis manusia yang meliputi setiap perilaku mental yang berhubungan dengan pemahaman, pertimbangan, pengolahan informasi, pemecahan masalah, kesengajaan dan keyakinan. Ranah kejiwaan yang berpusat di otak ini juga berhubungan dengan konasi (kehendak) dan afeksi (perasaan) yang bertalian dengan ranah rasa (Chaplin, 1972:22).

Dengan demikian dapat dipahami prestasi kognitif adalah suatu hasil usaha yang diperoleh siswa dari keterlibatannya dalam proses belajar mengajar yang berhubungan 
dengan daya ingat siswa setelah mengikuti proses belajar. Secara singkat prestasi kognitif merupakan kinerja akademik yang bertumpu pada ranah cipta yang berpusat di otak atau intelegensi (IQ).

Pendidikan agama Islam terjadi dengan adanya partisipasi orang tua dan guru ada dua bentuk, yaitu partisipasi di dalam rumah dan partisipasi di sekolah. dalam meningkatkan mutu pendidikan dapat dilakukan dengan : a) parenting, b) komunikasi interaktif guru dan orang tua, c) volunteering (membantu pembiayaan program sekolah anak dan ikut serta orang tua dalam program sekolah), d) belajar di rumah, e) mengambil keputusan bersama dalam melaksanakan program sekolah anak, f) guru dan orang tua bekerjasama dengan masyarakat, g) kunjungan rumah, h) menciptakan iklim lingkungan sekolah yang kondusif. Adapun faktor-faktor untuk memperkuat hubungan guru dan orang tua dalam mengembangkan mutu pendidikan anak di sekolah diantaranya : a) kepemimpinan guru dan orang tua dalam mendidik, b) hubungan dan kerjasama orang tua dan siswa, c) budaya sekolah, d) program kemitraan, e) jaringan komunitas, f) menjaga komunikasi orang tua dan guru dalam pencapaian perkembangan mutu pendidikan terutama perkembangan anak, g) evaluasi perkembangan mutu pendidikan anak dan perbaikannya, h) pembiayaan pendidikan, i) seminar dan pelatihan pendidikan.

Pendidikan Agama Islam adalah upaya sadar dan terencana dalam menyiapkan peserta didik untuk mengenal, memahami, menghayati, hingga mengimani, bertakwa, dan berakhlak mulia dalam mengamalkan ajaran agama Islam utamanya kitab suci AlQuran dan Al-Hadis, melalui kegiatan bimbingan, pengajaran, latihan, serta penggunaan pengalaman. Disertai dengan tuntunan untuk menghormati penganut adama lain dalam hubungannya dengan kerukunan antara umat beragama dalam masyarakat hingga terwujud kesatuan dan ppersatuan bangsa (Kurikulum PAI).

Menurut Zakiyah Daradjat (1987:87), Pendidikan Agama Islam adalah suatu usaha untuk membina dan mengasuh peserta didik agar senantiasa dapat memahami kandungan ajaran Islam secara menyeluruh, menghayati makna tujuan, yang pada akhirnya dapat mengamalkan serta menjadikan Islam sebagai pandangan hidup.

Tayar Yusuf (1986:35) mengartikan pendidikan Agama Islam sebagai usaha sadar generasi tua untuk mengalihkan pengalaman, pengetahuan, kecakapan, dan keterampilan kepada generasi muda agar kelak menjadi manusia muslim, bertakwa kepada Allah Swt, berbudi pekerti luhur, dan berkepribadian yang memahami, menghayati, dan mengamalkan ajaran agama Islam, dalam kehidupannya, sedangkan menurut A. Tafsir, Pendidikan Agama Islam adalah bimbingan yang diberikan seseorang kepada seseorang agar ia berkembang secara maksimal sesuai dengan ajaran Islam.

Peneliti mendapati beberapa karya ilmiah yang berupa penelitian tentang hubungan sikap siswa terhadap perhatian orang tua karir terhadap prestasi kognitif mereka pada mata pelajaran PAI yang peneliti anggap mempunyai relevansi dengan penelitian yang peneliti lakukan. Adapun beberapa hasil penelitian yang relevan dengan penelitian ini, adalah: 
Pertama penelitian berjudul "Pengaruh Persepsi Siswa Atas Perhatian Orang Tua Karir Terhadap Ritual Keagamaan Anak Di SD HJ. Isriati Semarang” Skripsi Rohana Hanif ( NIM: 05111079 ) pada tahun 2010, mahasiswi Fakultas Tarbiyah IAIN Walisongo Semarang, memberikan kesimpulan bahwa kesibukan dan kurangnya perhatian orang tua dapat mempengaruhi ritual keagamaan peserta didik, sehingga orang tua diharapkan dapat meningkatkan perhatian dan pengawasan.

Kedua Penelitian yang berjudul "Hubungan Antara Perhatian Orang Tua Dengan Prestasi Belajar Pendidikan Agama Islam Siswa Kelas VIII SMPN 2 Temon Kulon Progo" dilakukan oleh Siti Nur Azizah (2009) Tahun Pelajaran 2008/2009” Hasil penelitian menunjukan: 1) Tingkat perhatian oarang tua siswa kelas VIII SMPN 2 Temon berada pada kategori sedang/cukup dengan persentase 45,3\%. 2) Prestasi belajar PAI siswa kelas VIII SMPN 2 Temon pada kategori sedang dengan persentase sebesar $48,4 \%$. 3) Tidak terdapat hubungan positif yang signifikan antara perhatian orang tua dengan prestasi belajar PAI siswa kelas VIII SMPN 2 Temon Kulon Progo, sebab ro < rt $(0,037<0,202)$.

Ketiga penelitian berjudul "sikap siswa terhadap upaya guru dalam menumbuhkan suasana religius hubungannya dengan akhlak mereka sehari-hari" penelitian pada kelas 1 SMP Plus Al-Aqsha Jatinangor skripsi oleh Mubarok Izazi NIM (1211202097) UIN Sunan Gunung Djati Bandung dengan kesimpulan bahwa" ahlak siswa dipengaruhi oleh adanya arah sikap siswa terhadap upaya guru dalam menumbuhkan suasana religius.

\section{METODOLOGI PENELITIAN}

Pendekatan yang digunakan dalam penelitian ini adalah pendekatan kuantitatif, yaitu pendekatan penelitian untuk mendeskripsikan tren-tren dan menjelaskan hubungan di antara variabel yang ditemukan dalam kepustakaan. untuk melaksanakan penelitian ini, peneliti menetapkan pertanyaan-pertanyaan sempit, menemukan atau mengembangkan instrumen untuk mengumpulkan data guna menjawab pertanyaanpertanyaan penelitian, dan menganalisis angka-angka dari instrumen, dengan menggunakan statistik. Sedangkan Metode yang digunakan dalam penelitian ini adalah metode deskriptif, yaitu suatu penelitian yang diupayakan untuk mengamati permasalahan secara sistematis dan akurat mengenai fakta fakta dan sifat-sifat objek tertentu. Metode ini di pilih karena penelitian yang sedang dilakukan tidak hanya sebatas pengumpulan data melainkan dilanjutkan dengan pengolahan dan pengambilan kesimpulan yang dilengkapi dengan perhitungan statistik.

Jenis data yang digunakan untuk memecahkan masalah diatas yaitu dengan menggunakan jenis data primer. Dimana data primer adalah data yang diperoleh atau dikumpulkan langsung dilapangan oleh orang yang melakukan penelitian atau yang bersangkutan yang memerlukannya. Data primer ini disebut juga data asli atau data baru. Data primer dalam penelitian ini diperoleh secara langsung dengan menggunakan angket dan tes yang disebarkan kepada siswa selaku responden. Kemudian dikumpulkan, diolah dan disajikan oleh penelitian. Sedangkan sumber penelitiannya adalah Menurut Nanang Martono (2011:74) Populasi adalah keseluruhan obyek atau subyek yang berada pada 
suatu wilayah dan memenuhi syarat-syarat tertentu berkaitan dengan masalah penelitian, atau keseluruhan unit atau individu dalam ruang lingkup yang akan diteliti. Dalam arti lain keseluruhan subyek penelitian yang dapat dimintai informasi. Adapun populasi dalam penelitian ini adalah seluruh siswa kelas VII SMP Karya Budi Cileunyi Bandung.

Suharsimi Arikunto juga menjelaskan secara jelas dalam bukunya prosedur penelitian sebagai berikut" jika populasi (subyek) nya kurang dari 100, lebih baik diambil semua sehingga penelitiannya merupakan penelitian populasi. Selanjutnya jika jumlahnya besar (lebih dari 100), maka diambil antara 10-15\% atau 20-25\% atau lebih tergantung kepada:

1) Kemampuan peneliti dilihat dari segi waktu, tenaga dan dana.

2) Sempit atau luasnya wilayah peneliti dilihat dari setiap subyek karena hal ini tergantung banyak sedikitnya data.

3) Besar kecilnya resiko yang ditanggung oleh peneliti.

(Yahya Romadhon, 2012: 67-69)

Populasi dari penelitian ini adalah seluruh siswa kelas VII SMP Karya Budi Bandung yang berjumlah 128 siswa yang tersebar dalam 4 kelas. Dengan ini penulis mempedomani pendapat Suharismi Arikonto (1998:107) yang sudah terlihat jelas di atas bahwasannya penulis mengambil sampel $25 \%$ dari jumlah populasi, dengan perhitungan $(25 \times 128) \div 100=32$. Jadi berdasarkan perhitungan tersebut, maka penulis mengambil sampel dalam penelitian ini berjumlah 32 siswa. Lebih jelasnya, populasi dan sampel untuk penelitian ini dapat dilihat dari tabel dibawah ini: Jenis data yang digunakan untuk memecahkan masalah diatas yaitu dengan menggunakan jenis data primer.

Penelitian ini dilaksanakan mulai pada bulan Januari 2016 sampai dengan selesai. Penelitian ini dilakukan di sekolah SMP Karya Budi Bandung. Alasan penulis mengambil lokasi Penelitian di SMP Karya Budi Bandung adalah karena lokasi tersebut terdapat masalah yang akan di teliti. Dan tersedianya sumber data yang diperlukan serta lokasi yang dekat dengan peneliti sehingga dapat menghemat waktu dan biaya.

Di dalam mengumpulkan data ada dua yaitu dengan angket dan tes. Angket ini ditujukan kepada siswa kelas VII SMP Karya Budi Bandung sebagai responden dengan 20 item pernyataan yang harus dijawab oleh siswa.Bentuk angket ini terstruktur dari pertanyaan-pertanyaan yang disertai dengan jumlah arlternatif jawaban yang dikembangkan kedalam lima pilihan, mulai dari kemungkinan memilih a,b,c,d dan e. Bentuk penskorannya untuk pernyataan yang bersifat positif teknik penilaiannya $a=5$, $b=4, c=3, d=2$, dan $e=1$. Sedangkan untuk pernyataan yang negatif teknik penilaiannya adalah $a=1, b=2, c=3, d=4$, dan $e=5$. Sedangkan tes yang diberikan kepada siswa berupa 20 item pertanyaan dengan materi yang sebelumnya sudah mereka pelajari sebelumnya.

Teknil analisis Data yang telah terkumpul dengan menggunakan teknik dan metode tersebut dengan melibatkan dua variabel yaitu variabel $\mathrm{X}$ dan variabel $\mathrm{Y}$, kemudian dilakukan analisis parsial dan korelasional. 


\section{HASIL PENELITIAN DAN PEMBAHASAN}

Sebagaimana telah dikemukakan pada bab sebelumnya, bahwa untuk mengetahui realitas sikap siswa terhadap orang tua karir pada siswa kelas VII di SMP Karya Budi Bandung, maka diajukan sejumlah item angket kepada 32 orang siswa sebagai responden dalam penelitian ini. Angket tersebut memuat 20 item pernyataan yang dikembangkan dari 3 indikator, yaitu : mengurus keperluan material anak, menciptakan suasana Home bagi anak ( pemberian bimbingan dan nasehat), tugas pendidikan bagi anak (pengawasan terhadap belajar, pemberian motivasi dan penghargaan, pemenuhan fasilitas belajar)

Untuk memudahkan penilaian dalam menentukan skor bagi setiap responden yang memilih jawabatan atas item yang disebarkan, maka penentuan skor untuk masingmasing option per item. Untuk variabel $\mathrm{X}$ ini, teknik penyekoran pada pertanyaan positif terhadap setiap jawaban responden yaitu, 5 untuk alternatif jawaban a, 4 untuk alternatif jawaban b, 3 untuk alternatif jawaban c, 2 untuk alternatif jawaban d, dan 1 untuk alternatif jawaban e. Penafsiran perhitungannya dengan melihat kriteria sebagai berikut:

Skor $0,5-1,5=$ Sangat Negatif

Skor $1,5-2,5=$ Negatif

Skor $2,5-3,5=$ Sedang

Skor 3,5-4,5= Positif

Skor 4,5 - 5,5 = Sangat Positif

a. Menghitung nilai rata-rata yang menggunakan analisis tiap indikator sebagai berikut:

1) Mengurus keperluan material anak

Untuk indikator ini, diajukan 3 item pernyataan yaitu: item no 1, 2, 3. Item no 1, pernyataannya; saya mendapat uang jajan dari orang tua ! dari pernyataan ini ada 18 orang yang menjawab a, 12 orang yang menjawab $b$, dan tidak ada satu orangpun yang menjawab c, d, e. Dari data tersebut diperoleh angka rata-ratanya, yaitu $(18 \times 5)+(14 \times 4)$ $=90+56=146: 32=4,56$. Angka tersebut termasuk ke dalam kategori sangat positif karena berada pada daerah interval 4,5 - 5,5

Item no 2 pernyataannya; setiap pagi saya diberikan susu oleh ibu ! dari pernyataan ini ada 4 orang yang menjawab a, 8 orang yang menjawab b, 8 orang yang menjawab c, 8 orang yang menjawab d, dan 4 orang yang menjawab e. Diperoleh angka rata-ratanya yaitu $(4 \times 5)+(8 \times 4)+(8 \times 3)+(8 \times 2)+(4 \times 1)=20+32+24+16+4=96: 32=$ 3. Angka tersebut termasuk kedalam kategori sedang karena berada pada daerah interval $2,5-3,5$

Item no 3 pernyataannya; Ayah/Ibu saya tidak memberikan pakaian baru diawal tahun ajaran baru! dari pernyataan ini ada 2 orang yang menjawab a, 2 orang yang menjawab b, 9 orang yang menjawab c, 14 orang yang menjawab d, dan 5 orang yang menjawab e. Diperoleh angka rata-ratanya yaitu $(2 \times 5)+(2 \times 4)+(9 \times 3)+(14 \times 2)+(5 \times 1)$ $=10+8+27+28+5=78: 32=2,44$. Angka tersebut termasuk kedalam kategori negatif karena berada pada daerah interval $1,5-2,5$

Apabila ketiga item tersebut di rata-ratakan maka akan menghasilkan skor (4,56 $+3+2,44): 3=3,33$ dari hasil tersebut dapat disimpulkan sikap siswa terhadap perhatian 
orang tua karir pada indikator mengurus keperluan material anak berada pada daerah interval 2,5 - 3,5 yang termasuk kedalam kategori sedang.

2) Menciptakan suasana Home bagi anak

(a) Pemberian bimbingan

Untuk indikator ini, diajukan 3 item pernyataan yaitu: item no 7, 8, 9. Item no 7, pernyataannya; Ayah/Ibu meluangkan waktu senggangnya di malam hari untuk membantu menyelesaikan PR saya! dari pernyataan ini ada 7 orang yang menjawab a, 20 orang yang menjawab b, 2 orang yang menjawab c, 1 orang yang menjawab d, dan 2 orang yang menjawab e. Dari data tersebut diperoleh angka rata-ratanya, yaitu $(7 \times 5)+$ $(20 \times 4)+(2 \times 3)+(1 \times 2)+(2 \times 1)=35+80+6+2+2=125: 32=3,91$. Angka tersebut termasuk ke dalam kategori positif karena berada pada daerah interval 3,5 - 4,5

Item no 8 pernyataannya; ketika saya bertanya kepada Ayah/Ibu tentang pelajaran yang tidak dimengerti, Ayah/Ibu menanggapinya dengan serius! dari pernyataan ini ada 13 orang yang menjawab a, 18 orang yang menjawab b, 1 orang yang menjawab c, 8 orang yang menjawab $d$, dan tidak ada satu orangpun yang menjawab $d$, e. Diperoleh angka rata-ratanya yaitu $(13 \times 5)+(18 \times 4)+(1 \times 3)=65+72+3=140: 32=$ 4,38 . Angka tersebut termasuk kedalam kategori positif karena berada pada daerah interval $3,5-4,5$

Item no 9 pernyataannya; Ayah/Ibu mengatur waktu khusus kepada saya untuk belajar di rumah! dari pernyataan ini ada 12 orang yang menjawab a, 11 orang yang menjawab b, 4 orang yang menjawab c, 5 orang yang menjawab d, dan tidak ada satupun orang yang menjawab e. Diperoleh angka rata-ratanya yaitu $(12 \times 5)+(11 \times 4)+(4 \times 3)+$ $(5 \times 2)=60+44+12+10=126: 32=3,94$. Angka tersebut termasuk kedalam kategori positif karena berada pada daerah interval 3,5 - 4,5

(b) Pemberian nasehat

Untuk indikator ini, diajukan 3 item pernyataan yaitu: item no 4, 5, 6. Item no 4, pernyataannya; Ayah/Ibu menasehati saya agar belajar dengan sungguh-sungguh! dari pernyataan ini ada 27 orang yang menjawab a, 5 orang yang menjawab b, dan tidak ada satu orangpun yang menjawab c, d, e. Dari data tersebut diperoleh angka rata-ratanya, yaitu $(27 \times 5)+(5 \times 4)=135+20=146: 32=4,22$. Angka tersebut termasuk ke dalam kategori positif karena berada pada daerah interval 3,5 - 4,5

Item no 5 pernyataannya; Ayah/Ibu menyuruh saya untuk perlu belajar dengan rajin agar menjadi pintar ! dari pernyataan ini ada 24 orang yang menjawab a, 8 orang yang menjawab b, dan tidak ada satu orangpun yang menjawab c, d, e. Diperoleh angka rata-ratanya yaitu $(24 \times 5)+(8 \times 4)=120+32=152: 32=4,75$. Angka tersebut termasuk kedalam kategori sangat positif karena berada pada daerah interval 4,5 - 5,5

Item no 6 pernyataannya; ketika malas belajar, Ayah/Ibu menegur saya! dari pernyataan ini ada 9 orang yang menjawab a, 19 orang yang menjawab b, tidak ada satu orangpun yang menjawab c, 2 orang yang menjawab d, dan 2 orang yang menjawab e. Diperoleh angka rata-ratanya yaitu $(9 \times 5)+(19 \times 4)+(2 \times 2)+(2 \times 1)=45+76+4+2=$ 
$127: 32=3,97$. Angka tersebut termasuk kedalam kategori positif karena berada pada daerah interval 3,5-4,5

Apabila keenam item tersebut di rata-ratakan maka akan menghasilkan skor $(3,91+4,38+3,94+4,22+4,75+3,97): 6=4,20$ dari hasil tersebut dapat disimpulkan sikap siswa terhadap perhatian orang tua karir pada indikator menciptakan suasana Home bagi anak berada pada daerah interval 3,5 - 4,5 yang termasuk kedalam kategori positif.

3) Tugas pendidikan pada anak

(a) Pengawasan terhadap belajar anak

Untuk indikator ini, diajukan 4 item pernyataan yaitu: item no 10, 11, 12, 13. Item no 10, pernyataannya; Ayah/Ibu saya menanyakan kesulitan-kesulitan yang di hadapi ketika saya sedang belajar ! dari pernyataan ini ada 6 orang yang menjawab a, 19 orang yang menjawab b, 3 orang yang menjawab c, 2 orang yang menjawab d, dan 2 orang yang menjawab e. Dari data tersebut diperoleh angka rata-ratanya, yaitu $(6 \times 5)+$ $(19 \times 4)+(3 \times 3)+(2 \times 2)+(2 \times 1)=30+76+9+4+2=121: 32=3,78$. Angka tersebut termasuk ke dalam kategori positif karena berada pada daerah interval 3,5 - 4,5

Item no 11 pernyataannya; Ayah/Ibu mengingatkan saya tentang perlengkapan sekolah yang harus dibawa agar tidak ada yang tertinggal ! dari pernyataan ini ada 19 orang yang menjawab a, 10 orang yang menjawab b, 3 orang yang menjawab c, dan tidak ada satu orangpun yang menjawab d, e. Diperoleh angka rata-ratanya yaitu $(19 \times 5)$ $+(10 \times 4)+(3 \times 3)=95+40+9=144: 32=4,5$. Angka tersebut termasuk kedalam kategori positif karena berada pada daerah interval 3,5 - 4,5

Item no 12 pernyataannya; Ayah/Ibu menanyakan saya tentang bagaimana! belajar saya disekolah! dari pernyataan ini ada 9 orang yang menjawab a, 15 orang yang menjawab b, 6 orang yang menjawab c, 2 orang yang menjawab d, dan tidak ada satu orangpun yang menjawab e. Diperoleh angka rata-ratanya yaitu $(9 \times 5)+(15 \times 4)+(6 \times 3)$ $+(2 \times 2)=45+60+18+4=127: 32=3,97$. Angka tersebut termasuk kedalam kategori positif karena berada pada daerah interval 3,5 - 4,5

Item no 13 pernyataannya; Ayah/Ibu mencek apakah saya sudah belajar ! dari pernyataan ini ada 3 orang yang menjawab a, 18 orang yang menjawab b, 7 orang yang menjawab c, 4 orang yang menjawab d, dan tidak ada satu orangpun yang menjawab e. Diperoleh angka rata-ratanya yaitu $(3 \times 5)+(18 \times 4)+(7 \times 3)+(4 \times 2)=15+72+21+8=$ $116: 32=3,67$. Angka tersebut termasuk kedalam kategori positif karena berada pada daerah interval $3,5-4,5$

(b) Pemberian motivasi belajar anak

Untuk indikator ini, diajukan 4 item pernyataan yaitu: item no 14, 15, 16, 17. Item no 14, pernyataannya; jika hasil ulangan saya jelek Ayah/Ibu saya marah ! dari pernyataan ini ada 10 orang yang menjawab a, 9 orang yang menjawab b, 9 orang yang menjawab c, 3 orang yang menjawab d, dan 1 orang yang menjawab e. Dari data tersebut diperoleh angka rata-ratanya, yaitu $(10 \times 5)+(9 \times 4)+(9 \times 3)+(3 \times 2)+(1 \times 1)=50+36+$ $27+6+1=120: 32=3,75$. Angka tersebut termasuk ke dalam kategori positif karena berada pada daerah interval $3,5-4,5$ 
Item no 15 pernyataannya; Ayah/Ibu memberi semangat kepada saya untuk optimis! dari pernyataan ini ada 13 orang yang menjawab a, 14 orang yang menjawab b, 5 orang yang menjawab c, dan tidak ada satu orangpun yang menjawab d, e. Diperoleh angka rata-ratanya yaitu $(13 \times 5)+(14 \times 4)+(5 \times 3)=65+56+25=136: 32=4,25$. Angka tersebut termasuk kedalam kategori positif karena berada pada daerah interval 3,5 - 4,5

Item no 16 pernyataannya; Ayah/Ibu saya menjanjikan untuk memberikan sesuatu hadiah kepada saya ! belajar saya di sekolah ! dari pernyataan ini ada 18 orang yang menjawab a, 10 orang yang menjawab b, 2 orang yang menjawab c, 2 orang yang menjawab $d$, dan tidak ada satu orangpun yang menjawab e. Diperoleh angka rataratanya yaitu $(18 \times 5)+(10 \times 4)+(2 \times 3)+(2 \times 2)=90+40+6+4=140: 32=4,38$. Angka tersebut termasuk kedalam kategori positif karena berada pada daerah interval 3,5 $-4,5$

Item no 17 pernyataannya; ketika rapot saya mendapat nilai baik, Ayah/Ibu memberikan pujian! dari pernyataan ini ada 16 orang yang menjawab a, 13 orang yang menjawab b, 1 orang yang menjawab c, 1 orang yang menjawab d, dan 1 orang yang menjawab e. Diperoleh angka rata-ratanya yaitu $(16 \times 5)+(13 \times 4)+(1 \times 3)+(1 \times 2)+$ $(1 \times 1)=80+52+3+2+1=138: 32=4,31$. Angka tersebut termasuk kedalam kategori positif karena berada pada daerah interval 3,5 - 4,5

Apabila kesebelas item tersebut di rata-ratakan maka akan menghasilkan skor $(3,78+4,5+3,97+3,67+3,75+4,25+4,38+4,31+4,25+3,66+4,69): 11=4,11$ dari hasil tersebut dapat disimpulkan sikap siswa terhadap perhatian orang tua karir pada indikator tugas pendidikan bagi anak berada pada daerah interval 3,5 - 4,5 yang termasuk kedalam kategori positif.

(c) Pemenuhan fasilitas belajar anak

Untuk indikator ini, diajukan 3 item pernyataan yaitu: item no 18, 19, 20. Item no 18, pernyataannya; Ayah/Ibu membelikan alat tulis di awal tahun ajaran baru ! dari pernyataan ini ada 11 orang yang menjawab a, 18 orang yang menjawab b, 3 orang yang menjawab c, dan tidak ada satu orangpun yang menjawab d, e. Dari data tersebut diperoleh angka rata-ratanya, yaitu $(11 \times 5)+(18 \times 4)+(9 \times 3)+(3 \times 3)=55+72+9=$ $136: 32=4,25$. Angka tersebut termasuk ke dalam kategori positif karena berada pada daerah interval 3,5-4,5

Item no 19 pernyataannya; Ayah/Ibu biasa menyiapkan ruangan khusus untuk belajar saya ! dari pernyataan ini ada 7 orang yang menjawab a, 13 orang yang menjawab b, 7 orang yang menjawab c, 4 orang yang menjawab d, dan 1 orang yang menjawab e. Diperoleh angka rata-ratanya yaitu $(7 \times 5)+(13 \times 4)+(7 \times 3)+(4 \times 2)+(1 \times 1)=$ $35+52+21+8+1=117: 32=3,66$. Angka tersebut termasuk kedalam kategori positif karena berada pada daerah interval 3,5 - 4,5

Item no 20 pernyataannya; Ayah/Ibu saya membelikan baju seragam diawal tahun ajaran baru! dari pernyataan ini ada 10 orang yang menjawab a, 18 orang yang menjawab b, 3 orang yang menjawab c, tidak ada satu orangpun yang menjawab d, dan 1 orang yang menjawab e. Dari data tersebut diperoleh angka rata-ratanya yaitu $(10 \times 5)$ $+(18 \times 4)+(3 \times 3)+(1 \times 1)=50+90+9+=150: 32=4,69$. Angka tersebut termasuk kedalam kategori sangat positif karena berada pada daerah interval 4,5 - 5,5 
Apabila kesebelas item tersebut di rata-ratakan maka akan menghasilkan skor $(3,78+4,5+3,97+3,67+3,75+4,25+4,38+4,31+4,25+3,66+4,69): 11=4,11$ dari hasil tersebut dapat disimpulkan sikap siswa terhadap perhatian orang tua karir pada indikator tugas pendidikan bagi anak berada pada daerah interval 3,5 - 4,5 yang termasuk kedalam kategori positif.

Berdasarkan keseluruhan data yang diperoleh untuk variabel $\mathrm{X}$, maka dapat diketahui hasil rata-ratanya yaitu $=(3,33+4,20+4,11): 3=3,88$. Lebih jelasnya bisa di lihat dalam tabel berikut:

Realitas Sikap Siswa terhadap Orang Tua Karir

\begin{tabular}{|c|c|c|c|}
\hline No & Indikator & Skor & Kategori \\
\hline 1. & Mengurus keperluan material anak $(1,2,3)$ & 3,33 & Sedang \\
\hline 2. & $\begin{array}{l}\text { Menciptakan suasana home bagi anak } \\
\text { a. Pemberian pembimbingan }(7,8,9) \\
\text { b. Pemberian nasehat }(4,5,6)\end{array}$ & 4,20 & positif \\
\hline 3. & $\begin{array}{l}\text { Tugas pendidikan bagi anak } \\
\text { a. Pengawasan terhadap belajar anak } \\
(10,11,12,13) \\
\text { b. Pemberian motivasi belajar anak } \\
(14,15,16,17) \\
\text { c. Pemenuhan fasilitas belajar anak } \\
(18,19,20)\end{array}$ & 4,11 & Positif \\
\hline & Rata-rata & 3,88 & Positif \\
\hline
\end{tabular}

Untuk mengetahui realitas prestasi kognitif pada mata pelajaran PAI siswa kelas VII di SMP Karya Budi Bandung, penulis menggunakan analisis parsial per indikator dengan alat pengumpul data berupa tes. Tes ini berjumlah 20 item pertanyaan pertanyaan item tes ini meliputi indikator-indikator yaitu mengingat, memahami, mengaplikasikan, menganalisis, mengevaluasi

Adapun untuk penskoran jawabannya, penulis mengacu pada jenjang kualifikasi skala 100, artinya nilai bergerak dari 0 - 100 dengan kriteria sebagai berikut

$90-100=$ Amat Baik

$80-89=$ Baik

$70-79=$ Cukup

$60-69=$ Sedang

$50-59=$ Kurang

$\leq 49=$ Amat Kurang

a. Menghitung nilai rata-rata yang menggunakan analisis tiap indikator sebagai berikut:

1) Mengingat 
Untuk mendalami indikator ini, penulis mengajukan 4 pertanyaan yaitu item no $1,2,5,16$. Item no 1 diarahkan pada pertanyaan thaharah mengajarakan kepada kita agar selalu hidup ?. hasil jawabannya menunjukan 28 orang siswa menjawab benar dan 4 orang siswa menjawab salah. Nilai rata-ratanya adalah $28: 32 \times 100=87,5$ nilai tersebut berada pada rentang $80-89$, maka termasuk kedalam kategori baik.

Item no 2 diarahkan pada pertanyaan menyapu muka dan kedua tangan sampai siku dengan tanah suci pengganti wudhu/ mandi adalah. Hasil jawabannya menunjukan 25 orang siswa yang menjawab benar dan 7 orang siswa yang menjawab salah. Nilai rata-ratanya adalah $25: 32 \times 100=78,13$ nilai tersebut berada pada rentang $70-79$, maka termasuk kedalam kategori cukup.

Item no 5 diarahkan pada pertanyaan penyebab seseorang melakukan mandi besar adalah. Hasil jawabannya menunjukan 30 orang siswa yang menjawab benar dan 2 orang siswa yang menjawab salah. Nilai rata-ratanya adalah $30: 32 \times 100=93,75$ nilai tersebut berada pada rentang 90 - 100, maka termasuk kedalam kategori amat baik.

Item no 6 diarahkan pada pertanyaan berikut ini hal-hal yang dibolehkan bagi perempuan yang sedang haid kecuali. Hasil jawabanya menunjukan 24 orang siswa yang menjawab benar dan 8 orang siswa yang menjawab salah. Nilai rata-ratanya adalah 24 : $32 \times 100=75$ nilai tersebut berada pada rentang $70-79$, maka termasuk kedalam kategori cukup

Berdasarkan perhitungan diatas, maka rata-ratanya adalah $(87,5+78,13+93,75$ $+75): 4=334,38: 4=83,60$. Nilai tersebut berada pada rentang $80-89$. Hal ini berarti bahwa prestasi kognitif pada mata pelajaran PAI pada indikator mengingat termasuk ke dalam kategori baik

2) Memahami

Untuk mendalami indikator ini, penulis mengajukan 4 pertanyaan yaitu item no $4,7,8,11$. Item no 4 diarahkan pada pertanyaan berikut ini yang termasuk rukun tayamum adalah ?. hasil jawabannya menunjukan 22 orang siswa menjawab benar dan 10 orang siswa menjawab salah. Nilai rata-ratanya adalah $22: 32 \times 100=68,75$ nilai tersebut berada pada rentang $60-69$, maka termasuk kedalam kategori sedang.

Item no 7 diarahkan pada pertanyaan apabila tidak terdapat air , maka bersuci untuk menghilangkanhadas besar kecil maupun besar cukup dengan tayamum yaitu . Hasil jawabannya menunjukan 20 orang siswa yang menjawab benar dan 12 orang siswa yang menjawab salah. Nilai rata-ratanya adalah $20: 32 \times 100=62,5$ nilai tersebut berada pada rentang $60-69$, maka termasuk kedalam kategori sedang.

Item no 8 diarahkan pada pertanyaan jumlah makmum dalam salat berjamaah paling sedikit adalah. Hasil jawabannya menunjukan 5 orang siswa yang menjawab benar dan 27 orang siswa yang menjawab salah. Nilai rata-ratanya adalah $5: 32 \times 100$ $=15,63$ nilai tersebut berada pada rentang $\leq 49$, maka termasuk kedalam kategori amat kurang.

Item no 11 diarahkan pada pertanyaan makhluk allah SWT yang gaib terbuat dari nur atau cahaya, dengan wujud dan sifat-sifat tertentu adalah. Hasil jawabanya menunjukan 29 orang siswa yang menjawab benar dan 3 orang siswa yang menjawab 
salah. Nilai rata-ratanya adalah $29: 32 \times 100=90,63$ nilai tersebut berada pada rentang 90 -100, maka termasuk kedalam kategori amat baik.

Berdasarkan perhitungan diatas, maka rata-ratanya adalah $(68,75+62,5+15,63$ $+90,63): 4=237,51: 4=59,38$. Nilai tersebut berada pada rentang $50-59$. Hal ini berarti bahwa prestasi kognitif pada mata pelajaran PAI pada indikator memahami termasuk ke dalam kategori kurang

3) Mengaplikasikan

Untuk mendalami indikator ini, penulis mengajukan 4 pertanyaan yaitu item no $20,12,13,15$. Item no 20 diarahkan pada pertanyaan orang yang melakukan tayamum adalah orang yang sedang?. hasil jawabannya menunjukan 14 orang siswa menjawab benar dan 18 orang siswa menjawab salah. Nilai rata-ratanya adalah $14: 32 \times 100=$ 43,75 nilai tersebut berada pada rentang $\leq 49$, maka termasuk kedalam kategori amat kurang.

Item no 12 diarahkan pada pertanyaan sifat-sifat malaikat diantaranya adalah. Hasil jawabannya menunjukan 31 orang siswa yang menjawab benar dan 1 orang siswa yang menjawab salah. Nilai rata-ratanya adalah $31: 32 \times 100=96,86$ nilai tersebut berada pada rentang 90 - 100, maka termasuk kedalam kategori amat baik.

Item no 13 diarahkan pada pertanyaan berikut ini yang bukan merupakan perbedaan antara malaikat dengan manusia adalah. Hasil jawabannya menunjukan 14 orang siswa yang menjawab benar dan 18 orang siswa yang menjawab salah. Nilai rataratanya adalah $14: 32 \times 100=43,75$ nilai tersebut berada pada rentang $\leq 49$, maka termasuk kedalam kategori amat kurang.

Item no 15 diarahkan pada pertanyaan Zaid mengerjakan soal ujian tanpa mencontek, walaupun banyak kesempatan di saat tidak ada pengawas diruangan sikap tersebut menunjukan bahwa ia tidak mau di catat jika oleh malaikat?. Hasil jawabanya menunjukan 18 orang siswa yang menjawab benar dan 14 orang siswa yang menjawab salah. Nilai rata-ratanya adalah $18: 32 \times 100=56,25$ nilai tersebut berada pada rentang $50-59$, maka termasuk kedalam kategori kurang.

Berdasarkan perhitungan diatas, maka rata-ratanya adalah $(43,75+96,86+43,75$ $+56,25): 4=325,75: 4=81,44$. Nilai tersebut berada pada rentang $80-89$. Hal ini berarti bahwa prestasi kognitif pada mata pelajaran PAI pada indikator mengaplikasikan termasuk ke dalam kategori baik.

4) Menganalisis

Untuk mendalami indikator ini, penulis mengajukan 4 pertanyaan yaitu item no $9,10,16,17$. Item no 9 diarahkan pada pertanyaan pahala salat berjamaah lebih banyak di banding salat sendirian, yaitu? hasil jawabannya menunjukan 30 orang siswa menjawab benar dan 2 orang siswa menjawab salah. Nilai rata-ratanya adalah $14: 30 \times$ $100=93,75$ nilai tersebut berada pada rentang $90-100$, maka termasuk kedalam kategori amat baik.

Item no 10 diarahkan pada pertanyaan hal-hal yang menjadi alasan diperbolehkan seorang muslim melakukan salat secara munfarid adalah. Hasil jawabannya menunjukan 29 orang siswa yang menjawab benar dan 3 orang siswa yang 
menjawab salah. Nilai rata-ratanya adalah $29: 32 \times 100=90,63$ nilai tersebut berada pada rentang $90-100$, maka termasuk kedalam kategori amat baik.

Item no 16 diarahkan pada pertanyaan salah satu persamaan antara malaikat dan jin adalah keduanya sama-sama ?. Hasil jawabannya menunjukan 30 orang siswa yang menjawab benar dan 2 orang siswa yang menjawab salah. Nilai rata-ratanya adalah 30 : $32 \times 100=93,75$ nilai tersebut berada pada rentang $90-100$, maka termasuk kedalam kategori amat baik.

Item no 17 diarahkan pada pertanyaan sifat malaikat yang membedakannya dengan manusia adalah?. Hasil jawabanya menunjukan 20 orang siswa yang menjawab benar dan 12 orang siswa yang menjawab salah. Nilai rata-ratanya adalah $20: 32 \times 100$ $=62,5$ nilai tersebut berada pada rentang $60-69$, maka termasuk kedalam kategori sedang.

Berdasarkan perhitungan diatas, maka rata-ratanya adalah $(93,75+90,63+93,75$ $+62,5): 4=340,63: 4=85,16$. Nilai tersebut berada pada rentang $80-89$. Hal ini berarti bahwa prestasi kognitif pada mata pelajaran PAI pada indikator menganalisis termasuk ke dalam kategori baik.

5) Mengevaluasi

Untuk mendalami indikator ini, penulis mengajukan 4 pertanyaan yaitu item no $3,18,14,19$. Item no 3 diarahkan pada pertanyaan yang termasuk kedalam hadas kesil adalah kecuali?. hasil jawabannya menunjukan 12 orang siswa menjawab benar dan 20 orang siswa menjawab salah. Nilai rata-ratanya adalah $12: 30 \times 100=37,5$ nilai tersebut berada pada rentang $\leq 49$, maka termasuk kedalam kategori amat kurang.

Item no 18 diarahkan pada pertanyaan iman kepada malaikat termasuk rukun iman yang ke?. Hasil jawabannya menunjukan 17 orang siswa yang menjawab benar dan 15 orang siswa yang menjawab salah. Nilai rata-ratanya adalah $17: 32 \times 100=53,13$ nilai tersebut berada pada rentang 50 - 59, maka termasuk kedalam kategori kurang.

Item no 14 diarahkan pada pertanyaan berikut ini adalah hikmah dari beriman kepada malaikat Allah SWT antara lain?. Hasil jawabannya menunjukan 29 orang siswa yang menjawab benar dan 3 orang siswa yang menjawab salah. Nilai rata-ratanya adalah $29: 32 \times 100=90,63$ nilai tersebut berada pada rentang $90-100$, maka termasuk kedalam kategori amat baik.

Item no 19 diarahkan pada pertanyaan sifat-sifat dan perilaku malaikat antara lain kecuali?. Hasil jawabanya menunjukan 29 orang siswa yang menjawab benar dan 3 orang siswa yang menjawab salah. Nilai rata-ratanya adalah $29: 32 \times 100=90,63$ nilai tersebut berada pada rentang $90-100$, maka termasuk kedalam kategori amat baik.

Berdasarkan perhitungan diatas, maka rata-ratanya adalah $(37,5+53,13+90,63$ $+90,63): 4=271,89: 4=67,97$. Nilai tersebut berada pada rentang $60-69$. Hal ini berarti bahwa prestasi kognitif pada mata pelajaran PAI pada indikator mengevaluasi termasuk ke dalam kategori sedang.

Berdasarkan keseluruhan data yang diperoleh untuk variabel $\mathrm{Y}$, maka dapat diketahui hasil rata-ratanya yaitu $=(83,60+59,38+81,44+85,16+67,97): 5=75,51$. Lebih jelasnya dilihat dalam tabel berikut: 
Realita Prestasi Kognitif Siswa Pada Mata Pelajaran PAI

\begin{tabular}{|c|l|c|c|}
\hline No & \multicolumn{1}{|c|}{ Indikator } & Skor & Kategori \\
\hline 1. & Mengingat $(1,2,5,6)$ & 83,60 & Baik \\
\hline 2. & Memahami $(4,7,8,11)$ & 59,38 & Kurang \\
\hline 3. & Mengaplikasikan $(20,12,13,15)$ & 81,44 & Baik \\
\hline 4. & Menganalisis $(9,10,16,17)$ & 85,16 & Baik \\
\hline 5. & Mengevaluasi $(3,18,14,19)$ & 67,97 & Sedang \\
\hline & Rata-rata & 75,51 & Cukup \\
\hline
\end{tabular}

Sebagaimana telah dijelaskan pada bab sebelumnya bahwa penelitian ini akan diarahkan terhadap penelitian sikap siswa terhadap perhatian orang tua karir dengan prestasi kognitif mereka pada mata pelajaran PAI untuk mengetahui ada tidaknya pengaruh tersebut, diperlukan adanya uji korelasioner. Berdasarkan hasil perhitungan yang di terdapat pada lampiran, ternyata kedua variabel tersebut berdistribusi normal dan regresinya linear, maka korelasinya dengan pendekatan product moment, menghasilkan nilai sebesar $-0,09$ pada taraf signifikansi 5\%. Sedangkan uji hipotesis harga $t_{\text {hitung }}$ yang diperoleh adalah $(-0,52)$ sedangkan harga $t_{\text {tabel }}(2,042)$. Dalam keadaan demikian maka Ha di tolak. Hipotesis yang diajukan ditolak artinya semakin positif sikap siswa terhadap perhatian orang tua karir diberikan kepada anak maka tidak berkorelasi dengan prestasi kognitif mereka pada mata pelajaran PAI. Uji Pengaruh variabel $\mathrm{X}$ terhadap variabel $\mathrm{Y}$ dapat diketahui bahwa derajat pengaruh sikap siswa terhadap perhatian orang tua karir (variabel $\mathrm{X}$ ) dengan prestasi kognitif mereka pada mata pelajaran PAI (variabel Y) sebesar 5\%. Angka tersebut menyatakan bahwa ada faktor lain yaitu sebesar $95 \%$ yang mempengaruhi prestasi kognitif mereka pada mata pelajaran PAI.

\section{HASIL PENELITIAN DAN PEMBAHASAN}

Realitas sikap siswa terhadap perhatian orang tua karir di analisis dengan menggunakan indikator mengurus keperluan material anak, menciptakan suasan Home bagi anak (pemberian pembimbingan dan pemberian nasehat), dan tugas pendidikan bagi anak (pengawasan terhadap belajar anak, pemberian motivasi belajar anak, dan pemenuhan fasilitas belajar anak). Dari semua inikator yang sudah di jelaskan di atas masing-masing sudah di ketahui hasil rata-rata perindikatornya dengan menggunakan alat pengumpul data berupa angket sehingga dalam realitas variabel $\mathrm{X}$ ini termasuk pada kategori positif. Berdasarkan skala rata rata 3,88. Yang berada diantara 3,5-4,5 dengan kualifikasi positif 
Realitas prestasi kognitif siswa pada mata pelajaran PAI dianalisis menggunakan indikator mengingat, memahami, mengaplikasikan, menganalisis, mengevaluasi melalui alat pengumpulan data berupa tes. ). Dari semua inikator yang sudah di jelaskan di atas masing-masing sudah di ketahui hasil rata-rata perindikatornya dengan menggunakan alat pengumpul data berupa angket sehingga dalam realitas variabel y ini termasuk pada kategori cukup. Berdasarkan nilai rata-rata 75,51. Yang berada pada rata-rata nilai 70 79 dengan kualifikasi cukup.

Hubungan antara sikap siswa terhadap perhatian orang tua karir dengan prestasi kognitif mereka pada mata pelajaran PAI adalah sebagai berikut (a) koefisien korelasinya Termasuk pada kategori sangat lemah. Berdasarkan skala angka -0,09; (b) hipotesisnya di tolak. Berdasarkan hasil yang diperoleh bahwa harga $t_{\text {hitung }}(-0,52)<$ harga $t_{\text {tabel }}(2,042)$. Artinya semakin positif sikap siswa terhadap perhatian orang tua karir diberikan kepada anak, maka tidak berkorelasi dengan prestasi kognitif mereka pada mata pelajaran PAI. Dan (c) Besarnya derajat pengaruh variabel $\mathrm{X}$ terhadap variabel $\mathrm{Y}$ sebesar 5\%. Hal ini menunjukan masih ada 95\% lagi faktor lain yang mempengaruhi prestasi kognitif mereka pada mata pelajaran PAI selain sikap siswa terhadap perhatian orang tua karir yang diberikan kepada anaknya dikelas VII SMP Karya Budi Bandung.

\section{SIMPULAN}

Berdasarkan hasil penelitian dan pembahasan mengenai hubungan sikap siswa terhadap perhatian orang tua karir dengan prestasi kognitif pada mata pelajaran PAI pada siswa kelas VII di SMP Karya Budi Bandung, maka dapat ditarik kesimpulan sebagai berikut :

1. Realitas sikap siswa terhadap perhatian orang tua karir termasuk pada kategori positif. Berdasarkan skala rata rata 3,88. Yang berada diantara 3,5-4,5 dengan kualifikasi positif

2. Realitas prestasi kognitif siswa pada mata pelajaran PAI termasuk pada kategori cukup. Berdasarkan nilai rata-rata 75,51. Yang berada pada rata-rata nilai $70-$ 79 dengan kualifikasi cukup.

3. Hubungan antara sikap siswa terhadap perhatian orang tua karir dengan prestasi kognitif mereka pada mata pelajaran PAI adalah sebagai berikut (a) koefisien korelasinya Termasuk pada kategori sangat lemah. Berdasarkan skala angka 0,09; (b) hipotesisnya di tolak. Berdasarkan hasil yang diperoleh bahwa harga $t_{\text {hitung }}(-0,52)<$ harga $t_{\text {tabel }}(2,042)$. Artinya semakin positif sikap siswa terhadap perhatian orang tua karir diberikan kepada anak, maka tidak berkorelasi dengan prestasi kognitif mereka pada mata pelajaran PAI. Dan (c) Besarnya derajat pengaruh variabel $\mathrm{X}$ terhadap variabel $\mathrm{Y}$ sebesar 5\%. Hal ini menunjukan masih ada 95\% lagi faktor lain yang mempengaruhi prestasi kognitif mereka pada mata pelajaran PAI selain sikap siswa terhadap perhatian orang tua karir yang diberikan kepada anaknya dikelas VII SMP Karya Budi Bandung. 


\section{SARAN}

Sejalan dengan hasil penelitian diatas, dapat dikemukakan beberapa saran sebagai berikut:

Kepada Guru PAI pertama, Sikap siswa terhadap perhatian orang tua karir yang diberikan kepada anaknya, di pandang sebagai unsur yang tidak berkorelasi dengan prestasi kognitif pada mata pelajaran PAI. Maka supaya prestasi kognitif siswa pada mata pelajaran PAI meningkat hendaknya tidak mempersoalkan sikap siswa terhadap perhatian orang tua karir yang diberikan kepada anaknya. Namun lebih memfokuskan pada aspek yang langsung berkaitan dengan prestasi tersebut. Misalnya anak lebih sering diberi tugas pada mata pelajaran tersebut dengan materi yang menyenangkan anak.

Kedua Mengingat masih ada faktor lain yang mempengaruhi prestasi kognitif mereka pada mata pelajaran PAI yaitu sebesar 95\%, maka hendaknya dilakukan upaya yang optimal dalam meningkatkan berbagai aspek yang sekiranya dapat mempengaruhi prestasi kognitif mereka pada mata pelajaran PAI. Misalnya memberikan stimulus yang baik sekiranya anak dapat belajar dengan lebih serius lagi.

Untuk calon peneliti bisa melakukan penelitian yang serupa dengan penelitian ini, misalnya penelitian berjudul hubungan sikap siswa terhadap perhatian orang tua karir dengan motivasi belajar mereka di sekolah.

\section{DAFTAR PUSTAKA}

Abror, A. J. (2009). Pola asuh orang tua karir dalam mendidik anak, (12)

Abu Ahmadi, Widodo Supriyono. Psikologi belajar. Jakarta: Rineka Cipta, 2013.

Ahmadi, Abu. Psikologi Sosial. Jakarta: PT Rineka Cipta, 2009.

Creswell, John. Riset pendidikan. yogyakarta: Pustaka Pelajar, 2015.

Diajukan, S., Agama, P., \& Oleh, I. (2015). Prestasi Belajar Pendidikan Agama Islam

Siswa Sdn 1 Ngetuk Nalumsari Jepara Tahun Cut Misni Nim 131310001083

Program Studi Pendidikan Agama Islam Fakultas Tarbiyah Dan Ilmu Keguruan

Universitas Islam Nahdlatul Ulama ( Unisnu ) Jepara Tahun 2015.

Djaali. Psikologi Pendidikan. Jakarta: PT Bumi Aksara, 2009.

Drs. Muhaimin, M.A.,. Paradigma Pendidikan Islam. Bandung: PT Remaja Rosdakarya, 2012.

Fatimah, Enung. Psikologi Perkembangan (perkembangan peserta didik). Bandung: CV Pustaka Setia, 2010.

Hasbiyallah, The Development Quality of Islamic Education, Procedeeng AICIS 2012.

Hayati, Tuti. pengantar statisika pendidikan. bandung: CV Insan Mandiri, 2014.

Ilmu, F., \& Dan, T. (2007). Pendidikan Agama Islam Fal < . ultas limn Tarbiyah dan Keguru n Universitas Islam Ncgeri Syarif Hidayatulloh.

Jamal Abdul Hadi, dkk. Menuntun buah hati menuju surga aplikasi pendidikan anak dalama perspektif islam. Surakarta: PT Era Adicitra Intermedia, 2011. 
Mahmud, Heri Gunawan, dkk. Pendidikan agama Islam dalam keluarga . Bandung: Akademia, 2012.

Majid, Abdul. Belajar Dan Pembelajaran (Pendidikan Agama Islam). Bandung: PT Remaja Rosdakarya, 2012.

Nasihuddin. Evaluasi Pembelajaran. Bandung: Tresna Bhakti Press, 2016.

Prihantoro, Agung. Kerangka Landasan untuk Pembelajaran, Pengajaran, Dan Asesmen. Yogyakarta: Pustaka Belajar, 2016.

Siregar, N. S. S. (2016). Persepsi Orang Tua terhadap Pentingnya Pendidikan bagi Anak. Jppuma, 1(1), 11-27. Retrieved from http://www.ojs.uma.ac.id/index.php/jppuma/article/view/548/877

Soemanto, Wasty. Psikologi Pendidikan (landasan kerja pemimpin pendidikan). Jakarta: PT Rineka Cipta, 2012.

Studi, P., Guru, P., Ibtidaiyah, M., Pendidikan, J., Madrasah, G., Ilmu, F., ... Ibrahim, M. (2015). Hubungan antara perhatian orang tua dengan prestasi belajar siswa bidang studi pai di madrasah ibtidaiyah negeri iii kabupaten malang.

Subana. Statistik Pendidikan. Bandung: CV Pustaka Setia, 2000.

Syah, Muhibbin. Psikologi Belajar. Jakarta: PT Rajagrafindo Persada, 2012.

Syah, Muhibbin. psikologi pendidikan dengan pendekatan baru. Bandung: PT Remaja Rosdakarya, 2016 